Mercator, Fortaleza, v. 17, e17031, 2018.

DOI: https://doi.org/10.4215/rm2018.e17031

ISSN: $1984-2201$

Copyright @ 2002, Universidade Federal do Ceará

\title{
CONQUEST OF HOME IN THE CANAÃ ALLOTMENT IN PASSO FUNDO, BRAZIL
}

\author{
KUJAWA, Henrique Aniceto; ${ }^{\text {a* }}$ ZAMBAM, Neuro José; ${ }^{b}$
}

(a) Doctor in Social Sciences. Professor Faculdade Meridional (IMED), Passo Fundo (RS), Brazil. ORCID ID: https://orcid.org/0000-0001-99909414. CURRICULUM LATTES: http://lattes.cnpq.br/3444336482458383

(b) PhD in Philosiphy. Professor: Faculdade Meridional (IMED), Passo Fundo (RS), Brazil. ORCID ID: https://orcid.org/0000-0001-5960-4237. CURRICULUM LATTES: http://lattes.cnpq.br/6893744456793355

\section{(*) CORRESPONDING AUTHOR}

Address: IMED/RS - Senador Pinheiro, 304, Bairro Rodrigues - Passo Fundo (RS) Brazil. CEP: 99070-220. Tel (+ 55 54) 30456100 E-mail: neuro.zambam@imed.edu.br

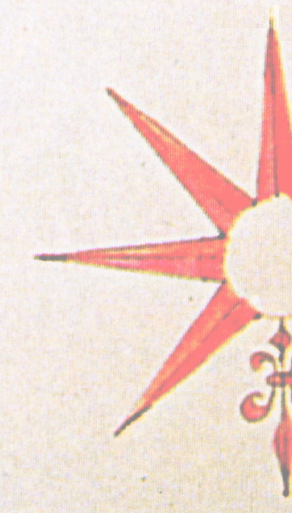

\begin{abstract}
Housing problems in Brazil are most common among the poorest social layers. Housing policies, which have increased remarkably in the last decade, remain deficient. The acquisition of decent housing goes beyond physical existence, reaching the right to the city and citizenship, connecting individuals to space and a community. The purpose of this case study, which includes a literature review, a focus group, interviews, and on-site visits and observations, is to analyze how the acquisition of property in the Canaã housing development, Passo Fundo, Rio Grande do Sul State, has contributed to the exercise of freedom and development, according to Amartya Sen's theory. The findings reveal that access to housing has increased freedom and development.
\end{abstract}

Keywords: Public housing policy. Agency. Amartya Sen.

\section{RESUMO / RESUMEN}

\section{CONOUISTA DA MORADIA NO LOTEAMENTO CANÃ̃ EM PASSO FUNDO, BRASIL}

A dificuldade de moradia no Brasil concentra-se nas camadas sociais mais pobres. As políticas habitacionais, com notável crescimento na última década, continuam deficientes. A conquista da moradia digna extrapola a existência material, atingindo o direito à cidade e à cidadania. Vincula os indivíduos a um espaço e a uma comunidade. $\mathrm{O}$ objetivo deste estudo de caso, que inclui revisão bibliográfica, grupo focal, entrevistas, visitas e observações in loco, é analisar como a conquista da moradia no loteamento Canaã contribuiu para o exercício da liberdade e do desenvolvimento, segundo Amartya Sen. Constatou-se que o acesso à moradia ampliou a liberdade e o desenvolvimento.

Palavras chaves: Política Pública de Moradia; Condição de agente; Amartya Sen.

\section{CONQUISTA DE LA VIVIENDA EN EL LOTEAMIENTO CANAÁN EN PASSO FUNDO,} BRASIL

La dificultad de vivienda en Brasil se concentra en las capas sociales más pobres, y las políticas habitacionales, con notable crecimiento en la última década, siguen siendo deficientes. La conquista de la vivienda digna extrapola la existencia material, alcanzando el derecho a la ciudad ya la ciudadanía, vinculando a individuos a un espacio ya una comunidad. El objetivo de este estudio de caso, que incluye revisión bibliográfica, grupo focal, entrevistas, visitas y observaciones in loco, es analizar cómo la conquista de la casa vivienda en la parcelación Canaán, Passo Fundo, Rio Grande do Sul, contribuyó para el ejercicio de la libertad y el desarrollo, según Amartya Sen. Se constató que el acceso a la vivienda amplió la libertad y el desarrollo.

Palabras-clave: Política pública de vivienda. Condición de agente. Amartya Sen. 


\section{INTRODUCTION}

The growth of urbanization has been a feature of Brazil's social organization in the past fifty years. This growth has been stimulated by technologies that transformed productive processes, by rural exodus and the economic and social dynamics produced by globalized capitalism. Davis (2006), in his work Planet of Slums, points out that the urbanization process is associated with the production of large metropolises and megalopolises. In 1950, there were 86 cities in the world with more than one million inhabitants, rising to 400 cities in 2006 and at least 550 cities in 2015.

In this urban scenario there has been an increase in social inequality and in the number of people living in slums. The data systematized by Davis (2006) are alarming. For instance, 78.2\% of the population in less developed countries lives in slums, accounting for one-third of the global urban population. Consequently, "[...] the price of this new urban order will be increasing inequality both within and between cities of different sizes and economic specializations." (DAVIS, 2006, p.18)

Harvey points out that the dynamics of urban organizations are associated with the capitalist model of development that transforms the urban space into the locus of capital production and reproduction under the aegis of profit: "It is my contention that urbanisation plays a particularly active role, (alongside other phenomena such as military expenditure), in absorbing the surplus product that capitalists ceaselessly produce in their search for profits." (HARVEY, 2014 p.33)

Housing deficit is associated with the increase of 'favelization', property speculation and the growth of social inequality in urban areas. Data collected by the Pinheiro Foundation (Fundação Pinheiro) show that in Brazil, in 2015, this deficit represented 6,186,503 million households, which accounted for $9.3 \%$ of permanent or improvised housing (FUNDAÇÃO PINHEIRO, 2017). The same analysis points out that this lack is concentrated in poorer social layers, which aggravates social inequality.

In contrast to this reality, there has been a notable advance in the formal recognition and affirmation of the right to the city and to housing. The Constitution of 1988, article 23, section IX, establishes the common remit of the Federal Government, States, the Federal District and municipalities "to promote housing construction programs and to improve housing conditions and basic sanitation." Subsequently, Constitutional Amendment No. 26, dated February 14, 2000, included in Article 6 of the Constitution, which refers to the right to housing embedded in all social rights: "Social rights include education, health, food, work, housing, leisure, security, welfare, maternity and child protection, and assistance to the destitute, according to this Constitution."

Accordingly, the City Statute recognizes the right of citizens to participate in the planning and structuring of urban spaces, establishing different participation instruments, such as master plans, public hearings, and the regulation of land use through Special Zones of Social Interest (ZEIS: Zonas Especiais de Interesse Social) and Urban Real Estate Tax (IPTU: Imposto Predial Territorial Urbano), progressively over time. In this sense, Harvey (2014: 28) points out: "the right to the city is therefore far more than an individual or group right of access to the resources that the city embodies: it is the right to change and reinvent the city according to our deepest wishes."

The housing policies developed in Brazil in the last century are associated with the aforementioned context. The first, as of 1920, were linked to savings banks and retirement and pension funds (CAPs / IAPs, acronyms in Portuguese) and, in 1946, to the Foundation of Low-Cost Housing (FCP - Fundação da Casa Popular). In the 1960s, the creation of the National Housing System (SNH: Sistema Nacional de Habitação), whose main funding institution was the National Housing Bank (BNH - Banco Nacional de Habitação), intensified the financing of houses for different social segments.

In 1986, the economic crisis and the federal government management model led to the closure of the BNH and made the Caixa Econômica Federal the main banking institution responsible for financing and managing housing policies. The 1980s and 1990s represented a hiatus in the national 
housing policy with programs fragmented over time and space as actions were left to states and municipalities.

In 1999, the creation of the Residential Lease Program (PAR - Programa de Arrendamento Residencial) ${ }^{1}$ represented the resumption, with greater consistency, of national housing policies. In the same vein, the approval of the City Statute (2001) and the creation of the Ministry of Cities (2003) stimulated the debate, planning and development of urban policies and, specifically, of more integrated housing. The 2008 global financial crisis, associated with the management model of the government at the time that attributed the role of stimulating job creation and economic growth to the state, contributed to the development of the Growth Acceleration Program (PAC - Pacto de Aceleração do Crescimento) and the My Home, My Life Program (MCMV - Minha Casa, Minha Vida). The latter included and expanded existing programs (PAR, Solidarity Credit Program - PCS, among others) and created other programs to finance housing for different income brackets.

Noteworthy in this study is the MCMV- Entities Program, which finances houses for the population with a family income up to $\mathrm{R} \$ 1,600.00$ (one thousand and six hundred Reals). These houses are self-managed constructions, with the mediation of a body established as a Legal Entity and monitoring by the Caixa Econômica Federal Bank. Although the roots of self-managed housing programs were in the 1970s and they were part of the demands of social movements in the context of the 1987/88 Constituent Assembly, their immediate predecessor was the Solidarity Credit Program, established in 2004. This type of financing was not significant, ${ }^{2}$ although it played an important role in the construction of houses and in the realization of the right to housing, associated with the expansion of citizenship of its beneficiaries. According to Mineiro and Rodrigues (2012, p. 21), this modality involves the beneficiaries "from the definition of the plot of land, the project, the technical team, building methods, the purchase of materials, the hiring of labor, the organization of work parties, accountability and the organization of community life".

This way of structuring public policies through the organization, involvement and participation of beneficiaries is in line with Sen's (2000) understanding. Sen states that the exercise of substantive freedoms and development policies are not restricted to the growth of the Gross National Product (GNP) or access to goods. That is, it involves other references such as political participation, the concrete exercise of democracy, the expansion of capabilities, fundamental freedoms and individuals' active agency. These dimensions are interconnected and potentialize each other. For Sen (2010), public policies, besides guaranteeing access to goods important for human life, broaden the conditions for human development and social balance.

The general objective of this article is to analyze the extent to which the MCMV-Entities Program contributes to the concrete exercise of freedom, to the expansion of active agency and to human and social development, as proposed by Sen, by prioritizing the following categories: development, capabilities, active agency and participation. This case study was carried out in the "Canaã Housing Development", in Passo Fundo, Rio Grande do Sul State, Brazil, financed by the MCMV-Entities Program and executed by the Unidos Venceremos Women's Group. The documents used to support this study were as follows: the Caixa Econômica Federal database, documentation of the entity (minutes, contracts, reports), as well as visits and in loco observation by the researchers. In addition, a Focus Group ${ }^{3}$ that involved the entity's board of directors, the project's technical personnel (engineer and social worker), the project manager and representatives of the beneficiaries (president of the Residents' Association) was created, and 10 interviews were carried out with the beneficiaries of the Canaã Housing Development project.

(1) Law number 11.977, of 7 July 2009.

(2) From 2009 to 2013, MCMV-Entities - known as Group 01 - was responsible for the granting of 17,000 of a total of 1.7 million housing units delivered by the Program throughout the country. In relation to the other subprograms that assist Group 1 of the MCMV Program (Business and Public Offer of Resources), the activities of the Entities correspond to 2.3\% of the contracts already signed and to $2.5 \%$ of the resources contributed for the entire Group 1 (CAMARGO, 2106; 2017). (CAMARGO, 2106; 2017).

(3) A Focus Group is a qualitative research technique that consists of meeting people selected by their profile to reconstruct and analyze a certain historical theme or context (GODIM, 2003). 
The focus group technique was chosen to allow the interaction of representatives of the subjects involved in the construction process, with the objective of understanding their perception of the project design, its implementation and the transformations that it promoted in the beneficiaries' lives. The interviews, characterized as an account of the lives of the people before and after participating in the Canaã Project, with minimal interference by the researcher, who allowed the participants to relate, as spontaneously as possible, their perceptions of the changes experienced. The selection of the interviewees was random and aimed to identify the extent to which the project promoted, along with housing, the expansion of capabilities and active agency.

This study is divided into four sections. First, the historical account of the Canaã Housing Development, highlighting the agents, the expectations, the deficiencies and the conquests. Second, the relationship of this experience with the development of capabilities. Third, the impact of this dynamic on the formation of active agency in the community. Fourth, the contributions to education and democracy, especially regarding the importance of spaces for participation.

\section{THE CANAÃ HOUSING DEVELOPMENT: HISTORICAL TRAJECTORY}

The Canaã Housing Development is located in a peripheral area of Passo Fundo, an extension of the Leonardo Ilha subdivision and near the historic São José neighborhood. The entity that presented the project to the Ministry of Cities was the Unidos Venceremos Women's Group, based in the Leonardo Ilha neighborhood. The Women's Group came into being in 1999, when a group of women who participated in the Leonardo Ilha Residents Association felt undervalued and, mainly, dissatisfied, because the association did not act effectively to improve the population's living conditions.

The Women's Group's first activity was the construction of a community nursery because most women could not hold formal jobs because they had no one to leave their children with. The nursery, which initially worked with the contribution of the users themselves, reached an agreement with the municipality and it is currently a Municipal Infant School (EMEI), managed by the Women's Group. The group's activities have diversified to meet new demands, and have developed cultural, leisure and even schooling activities for young people and adults through the Youth and Adult Literacy Movement Program (MOVA).

In 2006, as a result of the local reality, the Women's Group was challenged to act to reduce the housing deficit among low-income social layers, through the Solidarity Credit Program. One leader reports, “In fact, in the Women's Group we have worked with children a lot and spending time with their families - parents and children, we saw how they struggle to pay the rent" (Focus Group, September 2017) . In the years 2007-2008, this entity benefited 46 families with 21 new homes and 25 renovations and extensions.

The successful experience with the Solidarity Credit Program gave the entity accreditation to develop a project for the MCMV-Entities Program. The Canaã Project began in 2010, with the drafting of the project, selection of the land and the alteration of the master plan that transformed the rural area into a Special Zone of Social Interest (ZEIS) for the construction of 210 houses. The participants of the Focus Group emphasized that they faced many difficulties, mainly the uncertainty of approval, the need for resources even before the project was approved, and bureaucratic difficulties. One participant stated, “[...] I think that the greatest difficulty, like all other organizations, is that we worked voluntarily throughout the implementation of the project. We worked for a long time without being paid. It is completely voluntary work because until we found out whether the project had been approved and until the first funds arrived, we had no salary, nothing at all." (President of the Women's Group). The engineer, who has attended other entities, stated that it is not 
easy to execute these projects: "If everything is not well organized, in detail, it will not be approved. This [is not the] first project that had to go through this bureaucracy. I have worked for two other entities that could not get approval." (Engineer).

It was difficult to guarantee the purchase of the land during the course of the project. The owner demanded a deposit as security for the transaction. The first deal involved an area of 49,978.13 square meters for the construction of 117 houses. The entity needed to bring stakeholders together and convince them of the importance of participating in the project and, above all, of making financial contributions in advance, even without being certain that it would go ahead. The project's process was delayed and, therefore, the former owner demanded, the commitment of an adjacent area of $44.957 .80 \mathrm{~m}^{2}$ with a capacity for 93 houses as security.

The negotiation process involved the entity and also part of the future beneficiaries who were progressively participating in the project more effectively, taking on commitments and becoming an active agency in their achievements. The Focus Group highlighted the following:

This church [the location where the conversation with the group took place] was where the first meeting took place, where we planted the seed for everyone 'Look, this is how it works: if we want to buy the area, we have to secure it. 'How can we secure an area? With money. We did not have any money. We collected $\mathrm{R} \$ 250$ from each one at the time and we gave a check for $\mathrm{R} \$ 27,500$ to the owner of the area as a deposit to be kept until we finished the project, and everything was approved. (President of the Women's Group).

The approval of the project was granted in 2014. Construction work began in 2015 and should have been ready by 2017 . However, some difficulties in the execution of the project meant some houses were delivered in early 2018.

The first difficulty was the need to alter the way the construction company was hired to build the houses. Initially, the option was to hire a contractor that would build all the houses under a turn-key contract. However, failure to comply with the contract, the waste of materials and errors in the execution of the project made its conclusion unfeasible. The project manager emphasized the following:

What happened was, people want to make money, right? They're not interested if they use two bags of cement when they could have used one. What is important for them is to produce and get paid. So, unfortunately, the contractor you hire does not have the same vision as the owner, who is harmed by the waste of the bag of cement. (Project Manager).

As a result, the contract with the contractors was terminated and replaced by contracts with small service providers from the community or neighboring municipalities.

The second problem was City Hall's initial delay in paving the streets. The execution of the project had to be modified as, at the request of the beneficiaries, the paving was changed from cobblestone to asphalt. It was agreed with the Executive that the Canaã Housing Development would make the road foundation and the City Hall would lay the asphalt paving. The Focus Group reported the following:

And that was another improvement that we thought that was going to be a great thing. We changed from a cobblestone base to an asphalt base. Also, we exchanged the actual cobblestones to asphalt and the City Hall laid the asphalt layer for us. The costs with the City Hall were matched. (Engineer).

The delay in completing the asphaltic pavement caused two problems. The first was the impossibility of delivering the completed houses. Consequently, the expense of the partial construction of the road foundation has not been paid by the Caixa Econômica Federal bank because this work stage will only be finished when the asphalt paving is laid. The money invested in the partial 
paving work that has not been reimbursed by the Caixa Econômica Federal bank yet has led to a cash flow deficit, thus creating the second problem, which is the financial difficulty in concluding the houses that are still under construction. In addressing this problem, the Focus Group points to the difficult relationship with the municipal public power:

So, to sum up the story, to tell the truth, we had alternatives have everything ready, the paving, everything except the pump. We are depending on the council. We are about to stop work if the municipality does not do its part. Without the asphalt paving, we won't get paid, and the work will not be finished, and we won't deliver the houses. (Project manager).

The need to install a booster pump to propel sewage to the treatment plant is the third difficulty that has interfered with the schedule of the works. The Riograndense Sanitation Company (Companhia Riograndense de Saneamento-CORSAN) was unable to install the equipment, which prevents the delivery of the works by the Caixa Econômica Federal bank.

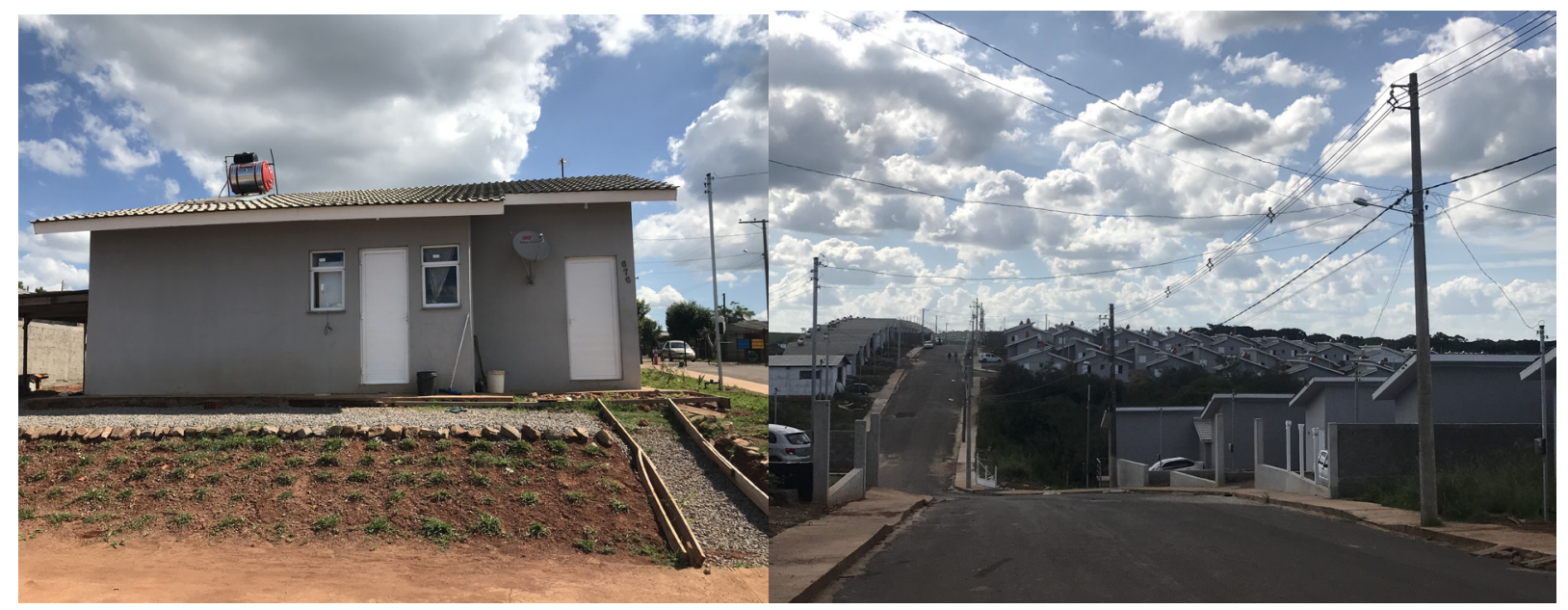

Figure 1 - Representation of the kind of house and a panoramic view of the Housing Development Source: Photographic archive of the authors of this study. December 2017.

Thus, by December 2017, 20 houses had been delivered and the remainder were scheduled for up to April 2018.

\section{THE CANAÃ PROJECT: PUBLIC POLICY THAT GENERATES CAPABILITIES}

The existence of Canaã Housing Development and the achievement of a dwelling place represent more than the construction of the development or a unique project that benefits a group of people with difficulties. The evaluation of a public policy, from its beginning, cannot be restricted to immediate goals or advantages, especially economic and social ones.

According to Sen (2000), public policies are considered conducive to development, which in turn is not only measured by the economic growth of a nation, group or the amount of material goods produced, consumption indexes or access to markets. ${ }^{4}$

Being aware of the generalized inequalities that characterize human existence, which are present in the differences of personal goals, physical composition, geographic environment and others,

(4) As Sen proposes, the public policy approach is founded in the importance of the person and the need for proper conditions for the development of capabilities. Thus, as a citizen, one should be an agent, acting as an organizer of policies for human promotion and combating inequalities, in the action of institutions or associations for the purpose of proposing, encouraging and administering in a propositional, participatory and cooperative manner to policies aimed at the common good and social equity, which is the first reason for its existence (ZAMBAM; KUJAWA, 2017, p. 65). 
the choice of capabilities as a criterion for the evaluation of personal development, social balance, conditions of participation and social justice represents the extension of a conception restricted to the conditions of social welfare.

The understanding of capabilities involves a set of decisive dimensions for the proposition, construction and effectiveness of public policies. From the priority of choosing to whom the public investments are destined, to the selection of individuals such as those living in the Canaã Housing Development of Passo Fundo city, it is essential to consider the perception of the constitutive diversities of society, short or medium term needs, and the real conditions of people's development, participation and integration. For example, the dynamics of such a project presupposes the beneficiaries' choice and the conditions for joint decision-making.

In this sense, Sen's definition (2000, p.95) is noteworthy:

A person's 'capability' refers to the alternative combinations of functionings that they can feasibly achieve. Capability is thus a kind of freedom: the substantive freedom to achieve alternative combinations of functionings (or, to put it less formally, the freedom to achieve various lifestyles). For example, an affluent person who fasts may have the same functional achievement in terms of eating or nourishment as a destitute person, who is forced to starve. However, the first person has a different 'capability set' than the second (the first can choose to eat well and be well nourished in a way the second cannot).

Specifically, in this context the importance of capabilities is related to conditions for making decisions freely. The potentialities or talents inherent in each human being can be developed through individual, social, political and cultural conditions or be obscured and buried if they do not find a social environment for their development. ${ }^{5}$

Capabilities are essential for the exercise of substantive freedoms. People using their capabilities can exercise their rights with autonomy, that is, as subjects of law according to the Federal Constitution of 1988 and characteristic of democratic societies. Access to good levels of education and information enables evolution in the process of integration, participation and decision in society. The Canaã Project demonstrates how this is possible, even if symbolically, and it indicates the conditions for amplifying the dimensions important for personal fulfilment, integration with others and influence for development. The agent's involvement in different actions enables the emergence of multiple talents, the exposition of interests and the capacity for interaction. As stated in the Focus Group,

[...] There were various axes that had to be dealt with - the development of the family, the community, the issues of cooperativism, environment and respect. So, several axes were compulsory developed, which the Ministry of Cities had said we should deal with. So we worked on these axes with the families. [...] we had two meetings a month. The first Saturday of the month, it was for Canaã 1 and the second was for Canaã 2. And, concomitantly, the topic of the meetings was also about monitoring the construction. So, they attended the meetings and the families also participated to find out the progress of the construction ... There were people who improved their actions in terms of relationships and now they understand their neighbors, family, and community. (Social Worker).

The perception of the power of public policies to enable people to make decisions freely is a difficult and even impossible process to evaluate in its entirety solely through scientific methods. The capability approach offers more complete frameworks to include indicators and perceptions, beyond economic or statistical metrics. This conviction makes it possible to consider public policies associated with actions that integrate individuals in social environments based on their options, possibilities and power of choice and, through numerous instruments, are able to overcome the

(5) The strengthening of the exercise of freedoms substantially depends on the broad network of more or less influential organizations that encourage, solidify and strengthen the building of capabilities. With their implementation, people have a varied array of options, whose operations enable them to seek what they consider important to do or to be". (ZAMBAM: 2014, p. 53). 
limitations that condition, impede, exclude or restrict their free and autonomous action. Sen (2000, p.335) emphasizes that:

It is important to emphasize the instrumental role of capability expansion in creating social change (going far beyond economic change). In fact, the role of human beings, even as instruments of change, can go far beyond economic production (to which the "human capital" perspective usually refers) and include social and political development.

Corroborating the same idea, a beneficiary who was interviewed commented on the change that occurred in her daily life because now she can do whatever she wants in the house, make whatever changes she wants and come and go as she wishes. Her eldest daughter, who still lives with her grandmother because she could not change schools, spends every weekend with her and says that the house will be hers. (Interview 7). Along the same lines, another interviewee commented that her nine-year-old son did not use to have any friends in the neighborhood because she has moved a lot. She was afraid to let her son play with the children on the street because she did not know who those children were, and she did not know their parents. (Interview 3).

Home ownership, which is the priority of this study, represents this set of indicators or references present in micro-actions, decisions and achievements of greater impact that benefit residents. When people no longer pay rent, they can organise their residence autonomously, choose how to enlarge the house and choose the color it will be painted. This represents the realization of the freedoms widely defended by Sen (2000: 335), "Expanding the freedoms that we have reason to value not only makes our lives richer and more unfettered, but also allows us to be fully social persons"

The Canaã Project, in addition to building houses, has developed a set of activities and used methodologies that enhance the development indicators described above (MUSSI, 2016). For instance, the implementation of the social project with actions that contribute to the increase of schooling levels, vocational courses and the improvement in interpersonal relationships. The focus group stresses:

Things have already changed a lot since they started, so much so that we have done a training project in partnership with some institutions to increase schooling levels, to increase professional training, [...]. So, since then, from the beginning when the project was approved, we have worked on several axes, from environmental to personal, family and community development. We were working on professional training, family, health, mental health, everything focusing on prevention and cooperativism. (Social Worker).

Supporting this perspective, one interviewee mentioned that her life completely changed after the acquisition of her own house. She reported that before she focused on survival, since she was always thinking about paying the rent, the difficulty her children suffered with the constant changes of neighborhood. Now she can manage her life, she can even focus on work ${ }^{6}$ better, which has enabled her to get two promotions and financial improvements.

After I got involved in the project, I've already got two promotions. Because before I could not focus on work. I went to work to fulfil my working hours, but could not do my best because I had that insecurity in my head. I thought about the instability of my children. After I saw my house getting off the ground, being built, I felt calmer because I knew that my son and I would have a place to live. (Interview 3)

When talking about what changed in her life after moving into the new house, the same beneficiary, emotionally reported, “(...) everything (....) now my children can visit me in my house.” (Interview 4)

Reinforcing Sen's understanding of capabilities, these are related to the conditions for individuals to make choices that are meaningful to their life and families. In this sense, the discourse of

(6) The interviewee is separated, mother of two children, and works for a cleaning company. 
the two interviewees mentioned above regarding the choices made possible by the management of what had previously been their rent money, shows the importance of this dimension for the exercise of autonomy and community integration. It should be noted that all the interviewees who used to pay rent when asked about the meaning of no longer paying rent, responded that "the rent was the first 'to sit at the table"", meaning that before buying food, they had to set aside money for rent, ${ }^{7}$ electricity, water and then buy food with what was left. One mother, who is the head of the family and has two children, was asked what she could do now that she had a house:

Better clothes, better shoes, traveling, I could not get out of Passo Fundo, but now I can. Now I'm planning a vacation trip for the end of the year. Before, I could never do that. Now I can dream, go after my dreams and give this pleasure to them (indicating her children). (Interview 3).

Other interviewees, a couple, ${ }^{8}$ who also had two children, answered, "the extra money has now being saved in a savings account for my little son. I want him to study, to do a course and to go to college. I want my son to be able to study. It was an opportunity that I, his father, did not have." (Interview 5)

The conditions for effective social participation comprise dynamics of the development of capabilities and the exercise of freedom. Access to housing represents the conditions to form one's individual, family and social identity. The status of dependence and obligation makes it impossible for one to act as an active agent. The Canaã Project is a constant exercise of this prerogative.

\section{THE CANAÃ PROJECT:}

\section{DEVELOPMENT, TRAINING AND ACTION OF THE ACTIVE AGENT}

Physical space, from a symbolic point of view, is an important guarantee of conditions for well-being as well as individual, family and community stability. In order to bring up children, housing is a reference that identifies relationships; it is the nucleus of coexistence between people, their varied life objectives and cultural tradition. In the organization and structuring of the Canaã Housing Development, these dimensions are well defined. However, Sen's perception offers indications for an approach beyond the conditions of access to social well-being.

In the interviews, the parents' statements showed the importance of having a house for their children, building interpersonal relationships and having educational possibilities. On interpersonal relationships, one of the beneficiaries spoke about the importance of living near a university that offers out-of-school hours projects, such as soccer and other sports. Another interviewee spoke of the possibility of her son having friends in the neighborhood, of being able to meet the parents of her son's classmates and also feeling at ease allowing them to play together. "Before, he did not say, 'Mom, I'm going to play at the neighbor's' because I would not allow him to go, because I did not know them, or if I allowed him to go, I would always be worried about him. Now, things are different. My son says, 'Mom, I'm going there', and I tell him he can go but should be careful crossing the street. I am fine with that now, because I know who the neighbors are". (Interview 3 ).

The mothers' speeches clearly show the change in the perspective on their families' future, in their children's routine and in their possibilities of coexistence. It is important to emphasize that this neighborhood relationship and the coexistence among children is not just the result of a new house, but also of the way the Canaã project was designed. It started even before the families moved

(7) One of the interviewees who works as a freelancer and whose wife is a domestic worker said, "whenever I was going to get a job, I had to think about putting aside R $\$ 600.00$ for rent because I did not want my family to live in the street (...) then, with what was left I used to buy food ". (Interviewee 7).

(8) They used to pay rent. The wife works as a domestic worker, and the husband as a night shift security guard. 
in to the housing development since their participation was encouraged in the meetings, as there were activities for the children, "these were not just meetings for adults. She (project coordinator) asked us to bring our children. So, the children could spend time together." (Interview 3 ).

The formation of an individual as an active agent implies a set of conditions, such as common needs for the exercise of the right to come and go. In the Canaã Housing Development, this perspective can be presented through several actions, such as the construction of the streets, the decision on the type of pavement, and the completion of the works of the sewage pumping station, as well as the equal importance of choices to guarantee the full participation of all. Regarding the diversity of ways of thinking and acting related to condition of the active agent, the following is noteworthy: "Besides the expression and affirmation of differences, pluralism enables a wide network of individual and collective opportunities that favor the formation of the identity of each person and the structuring of a social architecture that represents all its members." (ZAMBAM, 2014, p.54).

Considering the wide diversity of its members the social environment is tense and conflictive, which presupposes the capacity of all. In this case, especially in relation to the leaders, the exercise of tolerance, the clarity of the group's objectives, the clarification of legal requirements and the technical possibilities are crucial for the correct structuring and execution of the plan. ${ }^{9}$

The president of the Residents' Association highlights the importance of the social project's actions in daily life for the formation of active agency. In his testimony, it can be observed that awareness of belonging and being legal subjects implies effective participation in debates and decisions. The learning process involves the development of capabilities as a form of exercise of freedom and education for active agency.

[...] And then, people who see from outside know about its importance, about the need to raise awareness for the project, because it is important to do it. For us, it is something difficult, I mean, for those who are beneficiaries. So that all these things brought greater learning and, as a consequence, unity, it's still not much but it helped, it contributed to people's awareness, because we followed the project step by step. It gave some value to where I am today, and not only me but [...] in resocialization because there are people of every social class, culture and belief there. So, for coexistence, the participation and union of this group is important. (President of the Residents' Association).

The definition of an active agent clarifies dimensions and possibilities of evaluating the social effectiveness of public policies, both for their creation and conditions of justice. Social policies and the example in question are enlightening as to the need to overcome individualism and other forms of exclusion. In this sense, Sen clarifies that:

We can also see the person, in terms of agency, recognizing and respecting his or her ability to set goals, commitments, values, etc., and we can also see the person in terms of well-being, which also calls for attention. This dichotomy is lost in a model of exclusively self-interested motivation in which a person's agency must be entirely geared to their own well-being. But once that straitjacket of self-interested motivation is removed, it becomes possible to recognise the indisputable fact that the person's agency can very well be geared to considerations not covered - or at least not fully covered - by their own well-being. (SEN, 1999, p.57).

One of the interviewees said that the change began even before she entered the new house. She used to rent a place, then she went to live with her daughter and this made her very uncomfortable. After being selected by the Canaã Project, she began to live differently, with the hope and the possibility of owning her own house. She reported that she participated in all the meetings during the

(9) The social worker reports that a significant number of project participants had the opportunity to participate in training processes and this changed their behavior "If the people who took it seriously were taken into account from the start, there is a good number of families that followed and were making progress. There have been people who have improved even their relationships. Now they understand their neighbor, family, and community. "(Focus Group). 
construction of the houses. She did not miss any hearings or mobilization to make claims before the public authorities, and every Sunday ${ }^{10}$ she went to verify the progress of the works.

My husband asked me, "ohhh your house is there. Do you think it will run away if you do not go there every Sunday?" I answered, "Because it will be my house. (...)" At first when I saw the house's foundations , I cried - it was an emotional moment. You know how it feels to put aside a napkin, a spoon and say, 'I'm going to take these to my new house ... it's something that words cannot explain. (Interview 8).

The testimony of the president of the Residents' Association points to the difficulties of contemplating the set of interests due to the diversity of the individuals involved in the process. He also emphasizes that learning is a didactic-pedagogical exercise and allows the expansion of decision-making spaces and achievements, that is, the concrete exercise of active agency, not dependent exclusively on access to physical assets or structures. They have an instrumental character for personal fulfilment, social cooperation, the improvement of survival conditions and are crucial in the evaluation of social justice. The methodological view, after the experience as previously reported, demonstrates how the construction of the Canaã Housing Development contributed to the beneficiaries' involvement and development as agents: "And that really contributed ..., nowadays we do not remember everything ... but we are sure that people there who got involved ... have contributed a lot to the development and involvement." (President of the Association). Contrary to this, according to Sen (2000), passive agency is the result of aggravated reasons by the social reality through exclusion, discrimination or economic inequalities, as it is in the position of being assisted by the State or institutions without concern for their full social insertion. This passive status is aggravated when it reaches women, considering their strategic and symbolic mission in the transmission of values, in the process of insertion of individuals in society, in their ability to bring people together, overcome adverse situations, manage conflicts and strengthen human and social relationships in view of cooperation. Therefore, access to good levels of education, health and property rights is essential.

The denial of this prerogative substantially aggravates social policies, because the contribution of each individual, especially women, in strategic sectors as well as their participation according to their individual characteristics, is decisive for the whole project. Sen clarifies that in different circumstances and from empirical experiments that poverty reduction coupled with the expansion of female agency contributes greatly to development: "But it is also the case that the limited role of women's active agency seriously afflicts the lives of all people - men as well as women, children as well as adults "(SEN, 2000, p.222). The construction of equality presupposes the recognition of the constitutive inequalities of people and their repercussion in society.

The Canaã Project is coordinated and executed by an institution formed mostly by women that benefits primarily families in which women ${ }^{11}$ have a special performance, importance and responsibility. Data from technical social projects indicate that of the 210 families, 164 have women as the head of the family. Sen stresses that " the agency of women is one of the major mediators of economic and social change, and their determinations and consequences are closely related to many of the central features of the development process" (SEN, 2000, p.235).

The approach of active agency integrated to the public policies operated in the Canaã Project indicates the importance of associating projects of strong social repercussion aiming at human promotion to the development of capabilities, the exercise of freedoms and overcoming serious inequalities. The recognition of the insufficiency of the promotion of social welfare as a parameter of individual achievement and social justice calls for a perspective that encompasses the centrali-

(10) The construction site was open on Sundays for the beneficiaries to visit.

(11) The social worker thus refers to the process of choosing families and prioritizing women. "Then there were several people who could register, but preference was given to women who were the head of the family and had children and lower incomes. They would have more priority to participate in this project. " (Focus Group). 
ty of the individual as an active agent, and democracy as a process of citizen participation in the construction of alternatives aimed at social equity. The Canaã Project is a concrete demonstration of how this is possible.

\section{THE CANAÃ PROJECT AND THE EXERCISE OF DEMOCRACY IN THE PROCESS OF PARTICIPATION}

The participation of the population in collective decisions is an inalienable characteristic of democratic societies. Its denial prevents the development of countless basic aspects for personal fulfilment, social integration, political stability, and conditions of well-being. Public policies integrate the identity of democracies as State and government projects for meeting the needs of victims of social exclusion as a response to pressure from organized citizens, among other reasons.

Social and political organizations such as political parties, associations or institutions are fundamental for social evolution, the expression of will and existing conceptions within society and to illustrate the pedagogical character of education for democracy. The vitality of organized societies can be evaluated according to the conditions of organization and the expression of interests and objectives of groups and organizations. Contemporary deficiencies are denounced by Nussbaum (2015, p.77), who states that "Democracies all over the world are undervaluing, and consequently neglecting skills that we desperately need to keep democracies vital, respectful and accountable."

The process of construction and implementation of the Canaã Project - public policy associated with a government program with a wide reach and social acceptance - clarifies how the ideal of democracy, usually evidenced in mass expressions or passion in the electoral processes, can be accomplished daily in the life of a community with many needs.

The discussions, conflicts and interests of the Canaã Project are the expression of the vitality of democracy and of the process of building the active agency of each of the participants. Also, it demonstrates the dynamics of the constitution of capabilities. The real and authentic conditions of the expression of will, with more or less commitment, as an expression of each one's belief in the possibility of feeling like a subject of the process, to perceive talents or potentialities hitherto ignored or without a compatible environment for development, the exercise of power, the administration of resources, need to make new contracts as a result of unmet deadlines, the relationships with the City Hall and the Caixa Econômica Federal bank, the administration of bureaucracy with its demands usually foreign to the daily life of human relations, among other aspects. These demonstrate the need for training and education for democracy, starting from the participation of each one in the decisions that seek to implement a project that is vital for all.

The right to housing - established in the Federal Constitution of 1988 as one of the basic rights - and the housing solution projects have been building a significant part of the lives of those who manage to achieve home ownership. Moreover, they guarantee access to a material good that is fundamental for human survival. The acquisition of a house extrapolates the physical dimension of the house itself, even more so if the public policy that makes it viable, as in the case of Canaã, enables the possibility of social participation on equal terms, the structuring of family life as an expression of culture, dreams, beliefs and the necessary independence from pressure and oppression that impede human development. ${ }^{12}$

This development characterizes the dimension that impedes a utilitarian, exclusionary or subjugating relationship. As it is profoundly related to democracy, it has a preventive mission regarding the serious problems that affect the present, such as violence ${ }^{13}$ and meeting an immediate need.

(12) "How else might we think of the sort of nation and the sort of citizen we are trying to build? The primary alternative to the growth-based model in international development circles, and one with which I have been associated, is known as the Human Development paradigm." (NUSSBAUM, 2015, p.24).

(13) For an overview of the importance of public policies as ways of preventing social problems, consult Zambam; Ikert, 2011. 
The combination of these factors is an expression of citizenship and demonstrates the concrete possibilities of visualizing, evaluating and achieving social justice.

Overall, the interviewees highlight the importance of how the process of construction of the housing development was conducted, with clear rules and accountability at the periodic meetings, aiming at solidarity in the coexistence between the future residents. The perception of details of the testimony portrays the didactic-pedagogical relevance of education for citizenship, active agency and development of capabilities:

One of the topics dealt with in the meetings was accountability (...) she made very clear each thing that was being done, every step of the work, the finances. But, the key issue was the coexistence between neighbors. As I was always moving house, I did not have the opportunity to meet my neighbors, sit and talk to them (...) I was often afraid of getting attached to them. Here, with these meetings, I was able to get to know them. Nowadays, I know who my neighbors are, I hang out with them. (Interview 3).

She explained all the procedures of the construction of the housing development, of the houses, the problems of earthworks, asphalt (...). (Interview 7).

The widely-held view on the need to improve forms of participation in view of the formation of people as active agents for the development of capabilities has its origin in the exercise of discussion, daily participation and the construction of experiences with meaning that become references to the subsequent evolution. A prominent and recognized leaders of society, with the capacity for agglutination of the masses, the conditions to lead people and institutions in view of projects of political expression, begin their activities in their restricted circle of influence.

When talking about her participation in the construction of her house, one of the interviewees mentioned that the result of the house is the fruit of the project of the President of the Women's Group, but it is also her own achievement, since she participated in everything and concludes that she learned that she had to participate:

When December (2017) arrived, the house was not quite ready, but I went to speak to the Auntie ${ }^{14}$ and said, "My house is not finished. Give me the key and I will go finish it". She asked me, "Can you finish it?" I said, "Yes, my husband and I work. I want to finish my house. I want to be proud to say, "I put such a thing in my house. I did such a thing for my house ... I also want to do my part, to put in my own effort." (Interview 7).

This opportunity is unique and reveals the reach and power of democracy, as Sen (2000, p. 180) states:

Political and civil rights, especially those related to the guaranteeing of open discussion, debate, criticism and dissent, are central to the process of generating well-founded and reflected choices. These processes are crucial for the formation of values and priorities, and we cannot, in general, take preferences as given, irrespective of public discussion, that is, without taking into account whether or not discussions and dialogues are allowed.

The democratic process experienced during the implementation of the Canaã project reinforced the awareness of participation, either through the recognition of accountability, transparency, coexistence of residents and their families, or the need to continue the process. This can be identified in one of the interviews where the beneficiary mentioned that she wanted to participate in some way in the process of new elections in the Resident's Association of the housing development (Interview 8).

(14) Joselina, president of the Women's Group, is known to the residents as Auntie Negra, a nickname that came from the time she worked for Leonardo Ilha urban development day care center, as mentioned at the beginning of this article. 
The Canaã Housing Development has the essential elements for the construction of the identity of individuals deeply identified with the values and dynamics of democracy. Specifically, the participation process evidenced by this study confirms its contribution to education, training, and the improvement and exercise of democracy in this context, with the particularity of being a result of a public policy associated with establishing a constitutional right and with the potential to provide human development in its multiple dimensions.

\section{FINAL CONSIDERATIONS}

Public policies aimed at overcoming serious indicators of social inequality are the responsibility of the State. These policies are a fundamental instrument for human development, social balance, the integration of citizens into social life and education for democracy. The Canaã Project is part of this process and represents, both from a symbolic point of view and its organizational architecture and the model adopted by the Brazilian government, the expression of the conditions and possibilities to be a reference for public policies to overcome the alarming levels of exclusion of a significant percentage of people, especially the poorest and most vulnerable.

By adopting Sen's perspective and based on the objectives which initially provided information on the Canaã Project with its strategies of organization, decision-making and other involvements, it can be asserted that this Project contributed in a decisive, progressive and participatory way to the development of capabilities, active agency and, as a privileged referential of choice, education and the improvement of democracy.

Considering the lack of housing, especially for the poorest, it can be said that the major obstacles to the realization of this fundamental right, in addition to limited resources and the choice of governments, are related to excessive bureaucracy, which delay procedures and decisions, and predetermined deadlines that are difficult to meet. In addition, collective projects need to be chosen by everyone for everyone, in a cooperative way. This requires the exercise of leadership as rendering services for common objectives, the exercise of tolerance, knowledge of technical requirements, and recognition of the other as a subject of equal importance, rights and dignity.

The Canaã Project represents an important indicator for the expansion of the right to housing provided for in the Brazilian legislation, as an expression of the conditions for personal fulfilment, the social inclusion of people with diverse cultures and interests, the milieu for the development of capabilities, exercise of the condition of active agency and as an expression of individual and collective maturity, and finally, the conditions for the realization of democracy in people's daily life through a broad participation process.

\section{ACKNOWLEDGMENTS}

We are grateful to: The Focus Group's participants for their willingness to provide information. The beneficiaries interviewed who received us in their homes and were willing to provide information for this study; The Fundação Meridional for the "productivity" scholarship awarded to researchers; FAPERGS for the support through Edict 01/2017 - ARD.

\section{BIBLIOGRAPHIC REFERENCE}

BRASIL. Constituição da República Federativa do Brasil. Brasília: Federal Senate, 2008.

CAMARGO, C. M. MCMV Entidades: outras interações reguladoras pelo mercado. In: XVII ENANPUR - Desenvolvimento, Crise e Resistência: quais os caminhos do planejamento urbano e regional? São Paulo, 2017. Annals of the event. 
CAMARGO, C. M. Minha Casa Minha Vida Entidades: entre os direitos, as urgências e os negócios. São Carlos: Instituto de Arquitetura e Urbanismo (IAU USP) (Doctoral thesis), 2016.

DAVIS, M. Planet of slums. São Paulo: Boitempo, 2006.

FUNDAÇÃO JOÃO PINHEIRO. Déficit habitacional no Brasil 2015: resultados preliminares. Belo Horizonte : FJP, 2017.

GODIM, S. M. G. Grupos focais como técnica de investigação qualitativa: desafios Metodológicos. Paidéia, 2003,12(24), 149-161

HARVEY, D. Rebel Cities: From the right to the city to the urban revolution. Translated from English by Jeferson Camargo. São Paulo: Martins Fontes - stamp Martins, 2014.

MINEIRO, E. H.; RODRIGUES, E.. Do Crédito Solidário ao MCMV Entidades: uma história em construção In: LAGO, L. C. (Org.). Autogestão habitacional no Brasil. São Paulo: Letra Capital, 2012.

MUSSI, A. Leitura comunitária do futuro loteamento Canaã: senso de comunidade, expectativas e prioridades. INTERAÇÕES, Campo Grande, MS, v. 17, n. 4, p. 607-620, Oct./Dec. 2016.

NUSSBAUM, M. C. Not for profit: Why democracy needs the humanities. Translated from English by Fernando Santos. São Paulo: Martins Fontes, 2015.

SEN, A. On ethics and economics. Translated from English by Laura Teixeira Motta. São Paulo: Companhia das Letras, 1999.

SEN, A. Development as freedom. Translated from English by Laura Teixeira Motta. São Paulo: Companhia das letras, 2000.

ZAMBAM, N. J. A teoria da justiça de Amartya Sen: as capacidades humanas e o exercício das liberdades substantivas. In: EPISTEME NS, VOL. 34, N², 2014.

ZAMBAM, N. J.; KUJAWA, H. As políticas públicas em Amartya Sen: condição de agente e liberdade social. Revista Brasileira de Direito, Passo Fundo, vol. 13, n. 1, p. 60-85, Jan.-April. 2017.

ZAMBAM, N. J.; ICKERT, A. J. Pena privativa de liberdade: objetivo, fundamento e alternativas. In: Mauro G.; Natália F.G.(Org.). Direito contemporâneo em pauta. 1ed.Passo Fundo: Passografic, 2012, v. 1, p. 307-323. 